\title{
SURINAME EN DE KATOENCULTUUR
}

DOOR

\section{TJ. PYTTERSEN}

Suriname is een oud katoenproduceerend land. De katoencultuur werd er, tot arbeidsmoeilijkheden tengevolge van afschaffing der slavernij zich voordeden, met vrucht gedreven. Het terrein voor deze cultuur benut was dat gelegen in de onmiddellijke nabijheid der kust, waar grond en klimaat geschikt waren gebleken. De katoenuitvoer bedroeg in $1825: 1.164 .803$ K.G.

De laatste katoenplantage werd in 1885 gesloten. Rond de kampen der Indianen wordt nog steeds katoen aangetroffen, een Gossypium-varieteit ${ }^{\mathbf{1}}$ ).

Sedert de laatste jaren heeft het Departement van den Landbouw proeven met de Sea-Island katoen genomen op een oude plantage, Leydenshoop, in het Matappicagebied gelegen. Hoewel grondbewerking en onderhoud zeer onvoldoende zijn geweest, bedroeg de productie ongeveer 300 K.G. lint per H.A. Het gewonnen product werd door verschillende autoriteiten op katoengebied in Europa zeer gunstig beoordeeld. (Zie mijn aan de Regeering uitgebracht rapport.)

Alvorens verder te gaan met de beschouwingen over de levensvatbaarheid eener katoencultuur in Suriname, acht ik het gewenscht het een en ander mede te deelen over de wereld-katoencultuur in het algemeen.

\section{Noord-Amerika}

De zuidelijke Staten van Noord-Amerika nemen de eerste plaats in onder de katoenproduceerende landen. Het

1) Zie hieromtrent de Encycl. v. N. W.-Indië, bl. 400 e.v. 
Bureau voor Oogstramingen te Washington van het Amerikaansche Departement van Landbouw raamt de met katoen beplante oppervlakte in de Ver. Staten dit jaar op 38.287.000 acres tegen 34.852.000 acres het vorig jaar, 31.678 .000 acres in 1921 en 37.043.000 in 1920. De stand van den oogst op 25 Juni was $66.9 \%$ tegen 71.2 vorig jaar, en een 10 jaars gemiddelde van $76.0 \%$. Op deze basis wordt de oogst geschat op 11.412 .000 balen, tegen 11.065 .000 vorig jaar, 11.954 .000 balen in 1921 en 13.440.000 balen in 1920. De gemiddelde opbrengst per H.A. bedraagt hier dus ongeveer 200 K.G.

Katoen is de gewichtigste „commercial crop” der Ver. Staten. Zij is aldaar dikwijls de eenige cultuur der landbouwers. Hoewel verschillende soorten worden verbouwd neemt de kortstapelige katoen verreweg de voornaamste plaats in. De stapellengte dezer soort varieert van $3 / 4$ ${ }_{1}^{1} / \mathbf{1 6}$ inch. Deze lengte is in hoofdzaak afhankelijk van den grond waarop het product geteeld wordt.

De Sea-Island katoen (Gossypium barbadense) is inheemsch in tropisch Amerika. Het is een schitterend product met een stapellengte van $1^{1} / 2-2^{1} / 8$ inch, sterk, zeer fijn en zijdeachtig. De mooiste soort werd in Amerika geteeld op de eilanden langs de kust van Zuid Carolina. „At „present the boll weevil has practically stopped the grow„ing of Sea-Island cotton in the United States, the crop "of 1920 amounting to less than 2.000 bales of 500 pounds „each." (Overgenomen uit: The cotton situation U. S. Dep. of Agr. Yearbook 1921).

Men heeft echter in de nieuwe soort, Meade genaamd, een type gevonden, dat deze katoen kan vervangen. Meade heeft een zeer fijne sterke vezel met een lengte van $15 / 8$ tot $1^{3 / 4}$ inch.

De boll weevil, die zulk een enorme schade aan de katoencultuur in Noord-Amerika berokkend heeft en tot heden niet afdoende is kunnen worden bestreden, heeft de bevolking voordeel aangebracht, doordat hij oorzaak is geweest, dat de landbouwers de eenzijdige katoencultuur hebben verlaten en ook tot het verbouwen van andere gewassen, w.o. rijst een voorname plaats inneemt, zijn over- 
gegaan. Verschillende berichten in de literatuur wijzen op dit feit. Boven aangehaald werk zegt van deze boll weevilplaag o.m.: „The ravage of the boll weevil have caused „reductions in acreage in the worst infected areas. These „reductions have been offset by expansion of cultivated „areas in which the weevil has been less destructive."

De best produceerende katoenstreken in N. Amerika zijn Alabama, Mississipi en Texas, waar zwarte prairiegronden voorkomen, terwijl de goed draineerende „river bottom lands" voorkomende in Mississipi, Tennessee en Arkansas eveneens deze cultuur gunstige voorwaarden bieden. De zandige leemachtige kustlanden, mits goed bemest, leenen zich eveneens voor deze cultuur en produceeren flink. De nachtvorsten kunnen in de N. Amerikaansche katoenstreken groote schade veroorzaken.

Het werkvolkvraagstuk was vóór den oorlog in de Zuidelijke Staten niet lastig. De uit den oorlog teruggekomen werklieden weigerden niet alleen op de oude voorwaarden te werken, maar konden zich ook niet meer zoo gemakkelijk schikken in de daar heerschende toestanden. Daardoor en tevens door de groote vraag naar kleurling arbeiders in de Noordelijke Staten is er naar deze laatste streken een trek van uit het Zuiden gekomen, die thans dusdanige afmetingen heeft aangenomen, dat reeds gesproken wordt van een ondergang der katoencultuur tengevolge van gebrek aan arbeidskracht. Dit mag in vele opzichten overdreven zijn, een feit is het, dat de arbeidskosten en de arbeidsmoeilijkheden aldaar zeer gestegen zijn, waardoor de kostprijs der katoen belangrijk verhoogd is geworden. Deze kostprijs is tevens gestegen tengevolge van de noodzakelijkheid van het toenemend gebruik van meststoffen. Genoemd Jaarboek zegt: „Commercial fertil„izers are extensively used in the producing of cotton in „the South-eastern „States... . After labor, it is the most „important factor in the cost of producing cotton in these „Eastern States.”

"The variation in the net cost of lint cotton (het gezui„verd product) per pound on 783 farms illustrates the wide „range of costs”. Opgegeven worden „12 cents-\$3.78 
„per pound lint. One half of the cotton costs 35 cents and "less. The bulk of cotton, 85 per cent, was produced at a "cost up to 50 cents per pound."

\section{Britsch-Indië}

In „Handelsberichten” No. 828 van 25 Januari '23 komt het volgende bericht omtrent den katoenoogst in Britsch-Indië voor:

De volgende officieele gegevens, ontleend aan „The Indian Trade Journal", hebben betrekking, zoowel op de vroege als op de late katoensoorten; zij zijn gebaseerd op rapporten, loopende tot begin December 1922, welke ontvangen zijn uit de Britsche provincies en de Inlandsche staten, die gezamenlijk de geheele katoenstreek van Britsch-Indië omvatten. Het totale met katoen beplante oppervlak bedroeg toen 19.845.000 acres tegen 17.876 .000 acres op denzelfden tijd in 1921 ; een vermeerdering dus van $11 \%$. Vergeleken met de slotraming over 1921 (18.436.000 acres) komt men tot een vermeerdering van 8 pCt. De schatting begin December 1922 van de totale

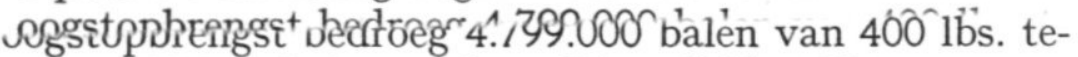
gen 4.336.000 balen op denzelfden tijd in 1921, eveneens een aangroei toonend van $11 \mathrm{pCt}$. Ook de vergelijking met de slotraming van den oogst in 1921, welke 4.464 .000 balen bedroeg, toont een aanwas van $8 \mathrm{pCt}$.

Het meergenoemd Jaarboek zegt over de katoencultuur in Indië o.m.: „The area denoted to cotton in India equals „about two thirds of the area planted in the U.St., but the "low yields per acre return a total crop about one third as „large."

Van de 11.000.000 ton bedragende katoenzaadproductie der wereld levert Britsch-Indië 2.000.000 ton.

\section{Egypte}

In Egypte bepaalt de katoencultuur zich tot de Nijldelta en een smalle strook langs deze rivier waarvan $1 / 3$ met katoen beplant wordt. Het totaal met dit product beplant oppervlak bedraagt ongeveer $1 / 20$ van dat der V. St., de hooge opbrengsten per akker zijn echter oorzaak dat de oogst $1 / 10$ van die van Noord-Amerika bedraagt. 
In de Soudan wordt thans „the Gezira Irrigation Project" uitgevoerd. Er wordt een dam in de Blauwe Nijl gemaakt bij Makwar, ongeveer 170 mijl bezuiden Khartoum gelegen, waardoor 100.000 akkers jaarlijks met katoen kunnen worden beplant. Whitaker (1923) voegt daaraan nog toe: „with unlimited scope for extension."

\section{Mesopotamië}

Whitaker zegt omtrent de katoencultuur in Mesopotamië: „Cotton growing is a developing industry and it is „estimated that Mesopotamia could yield 300.000 bales „annually if sufficient labour is forthcoming". Het is echter niet slechts het werkvolk waarvan deze uitbreiding afhankelijk is, ook het irrigatieplan Willcox speelt daarbij een zeer groote rol. Zoolang dat plan niet is uitgevoerd staat de landbouw daar bloot aan overstroomingsgevaar (dit jaar is reeds tweemaal tengevolge van het buiten de oevers treden van den Euphraat den landbouw aanzienlijke schade toegebracht).

\section{Andere Britsche koloniën}

Noord-Amerika streeft ernaar het op haar bodem gewonnen ruw materiaal zooveel mogelijk zelf te verwerken, om welke reden het de textielfabrieken uitbreidt en vermeerdert. Mede tengevolge van dit dreigend gevaar tracht Engeland in zijn groot koloniaal gebied de katoencultuur met kracht uit te breiden. In Bull. No. 386 October '20 van het Dep. of Agr. te Salisbury in Rhodesia schrijft H. W. Taylor o.m. het volgende:

„The cost of production in America last year was 24 „dollar cent per pound, and that of picking had worked "out 5 dollar cent per pound. The figures for the American "croparequoted, as that country supplies 85 per cent of the "cotton used in Great Britain.... In order to increase the "supply of raw material the Empire Cotton Committee is "making every effort to establish cotton growing in every "part of the British Empire where conditions are favourable "for cotton production $\left.{ }^{1}\right)$.... The two determining factors

\footnotetext{
1) Cursiveering door mij. P.
} 
„in cotton production are soil and climate. The soils which "give the best of cotton are sandy and clay loams and ",alluvial ${ }^{1}$ ) soils".

G. A. Lowry schrijft in de ,Journal of the Royal Society of Arts" van 20 April '23 o.m.:

„In view of the extremely high price of cotton and the „likelihood that it can never return to its former low level "- because of the boll weevil and the shortage and grow„ing inefficiency of negro labour in de southern states „it might be well for those endeavouring to raise cotton in „the Soudan and other British Possessions to know some of "the mechanical difficulties met in an endeavour to lighten "the labour costs in cotton production" 1). Hij schrijft aan het slot: „Handpicking has degenerated from 400 lbs per „day per hand (before abolition) to very little above 75 „lbs per day for the average (at present); so a mechanism „which will even bring it up to the original amount would be „a great gain providing it will do the same thing for the hoe",ing" 1 ).

\section{Zuid-Amerika}

Katoen groeit in Zuid-Amerika tot 28 grd. Z. Br. Hierdoor komt het noordelijk deel van Argentinië voor die cultuur in aanmerking. In verband hiermede wijs ik op een recent bericht in de Duitsche bladen, volgens hetwelk Hugo Stinnes aldaar groote stukken land heeft aangekocht, welke hij hoofdzakelijk voor de katoencultuur bestemd heeft.

Het groote katoenland der toekomst, wordt Brazilië genoemd. August Grieder haalt in een artikel ${ }^{2}$ ) over deze cultuur in dit land een uitspraak aan van Prof. Dr. A. Oppel (1902) die schrijft: „Sollte aber einmal aus irgendei„,nem Grunde Mangel an Rohstoff eintreten, so würde „kein Land seiner Naturlage nach besser imstande sein „,in die Bresche zu treten, als Brasilien; denn man kann „die Pflanze im ganzen Lande ziehen.” Dit mag overdre-

1) Cursiveering door mij. P.

2) „Der Tropenpflanzer” Oct. 1922. 
ven zijn, vaststaat dat dit gewas in een groot deel van Brazilië uitstekend slaagt. De slechte toestanden zoowel op landbouwkundig als ander gebied maken, dat tot heden deze cultuur niet tot volle ontwikkeling is gebracht. Grieder haalt verder een uitspraak aan van Dr. W. W. Coëlho de Souza, Superintendent van de katoenafdeeling van het Departement van Landbouw in Rio de Janeiro, die zegt: „Brasilien, speziell der Norden, ist, vom land„wirtschaftlichen Standpunkte aus betrachtet, im Ver„gleich mit den Vereinigten Staaten von Nord Amerika „um 60 Jahre zurück. Heute noch betreiben wir die glei„che Landwirtschaft, wie sie in jener Epoche unsere „Baumwollanbauer gekannt."

De streek waar op het oogenblik veel katoen met gunstig resultaat verbouwd wordt is gelegen tusschen den evenaar en 6 grd. ten zuiden van dezen. Aan de kust komen streken voor met eenzelfde klimaat als dat van Suriname; de regenval is echter anders. Zoo schrijft Mr. W. J. van Balen in zijn mooie werk: Zuid-Amerika (1920): „Het „klimaat van Pernambuco, dat in vroegere tijden even„eens vochtig was, heeft door het gestadig verdwijnen der „bosschen een wijziging naar den drogen kant ondergaan; "de regentijd laat daar, als in den geheelen Noord-Oost„hoek, soms maanden op zich wachten, waarbij inmiddels "de aarde in stof overgaat en de bevolking met paniek ge„slagen wordt; komt de bui dan eindelijk, dan valt er "veel te veel water ineens."

Maar ook meer landwaarts plant men katoen en hier schijnt de regenval meer gelijk aan dien van Suriname te zijn ${ }^{1}$ ).

Een der eerste factoren voor het slagen van de katoencultuur is, dat tijdens of na het in zaad schieten geen zware regenbuien voorkomen, die den oogst doen mislukken.

De uitgestrekte humushoudende vlakten aan de kust verschaffen de cultuur een zeer gunstigen voedingsbodem.

\footnotetext{
1) De regenval in het Amazone-gebied bedraagt jaarlijks $2000 \mathrm{mM}$. Bezuiden dit gebied komen tijden van langdurige droogte (secca's) voor.
} 
Ondanks het lage peil waarop de landbouwers in het noorden zoowel als in het noord-oosten van Brazilië staan, wordt aangenomen, dat aldaar de gemiddelde opbrengst per H.A. aan ongezuiverd product 1450 K.G. bedraagt, hetwelk overeenkomt met een opbrengst van $480 \mathrm{~K}$.G. lint. Grieder schrijft dan verder: „, . . . und auf nährstoff„reichen, bewässerbaren Böden ist eine Ernte pro Hektar „von 2400 bis 3000 KG. Samenbaumwolle bzw. 800 bis „1000 K.G. reine Fäser nichts aussergewöhnlich."

Wil de katoencultuur zich snel ontwikkelen dan is daarvoor nog veel arbeid en organisatie noodig.

Grieder schrijft: „Die Hauptanforderungen dabei sind: „1. Aufwendung grosser Kapitalien, zwecks Errichtung „,vollständiger Einrichtungen;

„2. dem Mangel an fortgeschrittenen Arbeitern ist „durch Einführung geeigneter landwirtschaftlicher Ma„schinen, speziell von Tractoren zu begegnen, um so mehr „,als auch die Zeit zur Bestellung grosser Ländereien durch „menschliche and tierische Kräfte allein zu kurz ist, d.h. "möglichst in allen Kulturarbeiten, von der Ackerbestellung „,bis zur Entkernung ist der Mensch durch die Maschine zu "ersetzen...." ${ }^{1}$ ).

Vooral de Staat Sao Paulo biedt deze cultuur zeer gunstige voorwaarden. Volledigheidshalve meen ik er op te moeten wijzen dat in vele der ook overigens voor katoen geschikte streken in Brazilië tijden van langdurige droogte voorkomen, waardoor zonder irrigatie het risico der cultures aldaar veel te groot is.

Het "Bull. of the Pan-American Union" van Januari '23 bevat een artikel: Irrigation in Brazil, van I.W. McConnel.

Gedurende 10 droge jaren viel in Ceara gem. 613 mM.,

$$
\text { ” } \quad 5 \text { natte }, \quad, \quad, \quad, \quad, \quad, \quad 2.316 \quad,,
$$

terwijl de gemiddelde regenval over 69 jaren 1420 mM. bedroeg.

Aan buitenlandsche firma's is thans opdracht gegeven tot het bouwen van de volgende dammen:

1) Cursiveering door mij. P. 


\begin{tabular}{l|r|r|r}
\hline \hline & $\begin{array}{l}\text { Topleng- } \\
\text { te in M. }\end{array}$ & $\begin{array}{c}\text { Hoogte } \\
\text { in M. }\end{array}$ & $\begin{array}{c}\mathrm{M}^{3} \text {. capaciteit der } \\
\text { basins. }\end{array}$ \\
\hline & 600 & 65 & 1.000 .000 .000 \\
Poço dos Paus & 450 & 50 & 2.500 .000 .000 \\
Oros & 350 & 50 & 340.000 .000 \\
Piranhas & 450 & 20 & 200.000 .000 \\
Pilões & 400 & 20 & 20.000 .000 \\
São Goncalo & &
\end{tabular}

Tevens worden door die firma's de irrigatiekanalen met de noodige verdeelwerken aangelegd. Men hoopt in 5 jaren dit groote werk gereed te hebben. „The land to be „placed beyond the effect of the drought is a great and „beautiful country, with established seaports and recog„nized busines systems.

"Its cotton alone is a potentiel resource. Its climate is „as attractive and its soil as fertile and productive as that "of the Southern California."

Ik wijs verder op de mogelijkheden die Peru en Venezuela de katoencultuur bieden. In „Handelsberichten” van 24 Mei '23 wordt in een mededeeling van H. Ms. Gezantschap te Caracas gewezen op de gunstige eigenschappen van een Peruaansche katoensoort „Tanguïs” genaamd voor Venezuela.

\section{Ons koloniaal gebied en de katoencultuur}

Het is een belang onzer textielindustrieelen het ruwe product geheel of gedeeltelijk in ons koloniaal gebied te winnen.

\section{Oost-Indië}

Ik geloof als vaststaand te mogen aannemen, dat in ons koloniaal gebied in Oost-Indië geen streken - behalve wellicht op Flores - worden aangetroffen, welke de katoencultuur bijzonder gunstige voorwaarden bieden, zoodat dit gebied voor goedkoop produceeren van katoen over het algemeen niet in aanmerkıng komt. 


\section{West-Indië}

De kleine eilanden hier buiten beschouwing latende is het hier de plaats na te gaan in hoeverre Suriname zich voor de katoencultuur leent. Hierbij wil ik de meer landwaarts gelegen streken waar de regenval voor deze cultuur ongunstiger is en het grondtype in vruchtbaarheid onderdoet voor het kustgebied buiten bespreking laten temeer waar in die streken nooit een plantage-katoencultuur heeft bestaan. Ik wil alleen aanstippen, dat volgens zeer voorloopige proeven de mogelijkheid niet is uitgesloten, dat die cultuur daar kans van slagen heeft.

Zooals ik boven reeds zeide, is een deel van het kustgebied der kolonie eertijds van beteekenis geweest voor de katoencultuur. In dit gebied komen zeer uitgestrekte met gras en biezen bedekte streken voor, waaronder er zijn van zeer groote vruchtbaarheid. (Zie „de W.-I. Gids” van Dec. 1922) ${ }^{1}$ ) Moeilijkheden met werkvolk waren in hoofdzaak aanleiding, dat deze cultuur aldaar niet langer met vrucht kon worden gedreven. Het rapport der StudieCommissie van het Suriname Studie Syndicaat zegt op blz. 105 van deze cultuur o.m.:

„Suriname heeft een niet scherp genoeg gemarkeerd „droog seizoen. Zware regenbuien tijdens of na het in „zaad schieten kunnen den oogst doen mislukken en dat „risico komt ons voor er vrij groot te zijn, afgezien van de „ernstige plagen, waardoor de cultuur bedreigd wordt. „Het bezwaar van ontijdige regenbuien moet voorheen „ook dikwijls tot teleurstelling hebben geleid, tenzij het „,klimaat zich in den loop der jaren gewijzigd mocht heb„ben”.

Risico loopen alle cultures; in de Zuidelijke Staten van Noord-Amerika zijn het de nachtvorsten, ontijdige regenbuien en insectenplagen, die daar de katoenvelden bedreigen.

Ik meen een oogenblik het gevaar der ontijdige regen-

1) De Encycl. van N. W.-Indië zegt omtrent de katoengronden in Suriname: „De beste gronden voor de katoen cultuur waren de biri-biri-landen, „lage met biezen begroeide vlakten en parwalanden, welke ingepolderd „,werden en drooggelegd." 
buien aan de kust van Suriname even te moeten nagaan. Vergeten dient niet te worden dat het aantal regendagen aan de kust, vergeleken met dat van het verder van de kust gelegen gebied, betrekkelijk gering is en de seizoenen scherper afgeteekend zijn. Ik acht het voor de waarde van dit opstel gewenscht den regenval van Nickerie 1907 t/m.1918 - te vermelden. De cijfers volgen hieronder. Daarbij dient in aanmerking te worden genomen, dat de droge tijd ongeveer medio Augustus invalt en gewoonlijk in November of December eindigt, terwijl in Maart het aantal buien wederom afneemt.

\begin{tabular}{r|r|r|r|r|r|r}
\hline \hline Jaar. & Aug. & Sept. & Oct. & Nov. & Dec. & Maart. \\
\hline 1907 & 44 & 83 & 2 & 78 & 58 & 378 \\
1908 & 336 & 51 & 46 & 51 & 105 & 200 \\
1909 & 216 & 37 & 28 & 16 & 140 & 144 \\
1910 & 197 & 44 & 30 & 54 & 272 & 127 \\
1911 & 84 & - & 52 & 98 & 73 & 284 \\
1912 & 67 & 72 & 10 & 103 & 213 & 10 \\
1913 & 32 & 58 & 18 & 27 & 247 & 44 \\
1914 & 136 & 84 & 33 & 102 & 82 & 114 \\
1915 & 77 & 9 & 11 & 49 & 147 & 37 \\
1916 & 304 & 34 & 24 & 67 & 274 & 64 \\
1917 & 174 & 256 & 19 & 49 & 182 & 170 \\
1918 & 29 & 4 & 13 & 23 & 104 & 134
\end{tabular}

Over 1919 kon ik geen cijfers vinden, voor 1920 echter wel; deze zijn:

$\begin{array}{llllll}102 & 39 & 23 & 36 & 75 & 66\end{array}$

De gemiddelde regenval in Nickerie bedraagt jaarlijks ruim 1800 m.M., terwijl die meer landwaarts 2300 m.M. bedraagt.

Gegevens omtrent het aantal en de grootte der buien konden mij niet worden verstrekt.

De cijfers toonen aan dat er jaarlijks drie maanden met weinig risico zijn voor het in zaad schieten en oogsten van het product. 
Voor ik verder ga meen ik de aandacht te moeten vestigen op een recent berichtje in een der Surinaamsche bladen: „Per jongste mailboot uit Nickerie ontving het land„bouwdepartement een partijtje katoen van ongeveer „1250 K.G., geteeld op het proefveld in Nickerie. Voor „zoover wij er over oordeelen konden is de kwaliteit schit„terend, het product ruim (de beplante oppervlakte was „,slechts vier akkers) en de kosten ruimschoots dekkend.

„Een monster Amerik. katoen, dat ons daarneven ver„toond werd, legde het daarbij af.

„Het partijtje zal naar Amerika verscheept worden, „waar er om gevraagd is. In Amerika zou in sommige „,kringen wel geneigdheid bestaan de katoencultuur hier „te ondernemen, wanneer het produkt goed blijkt te zijn „en de kosten niet te hoog, welke beide voorwaarden aan„wezig zijn.

„Eenige Amerikanen hebben reeds op Nickerie en Co„ronie het oog geslagen voor deze kultuur”.

De leider der katoenproeven in het Matappicagebied in de kolonie deelde mij mede, dat voor een geheel middels handenarbeid gedreven katoencultuur in Suriname één man per 4 akkers (1.7 H.A.) noodig is.

Een katoencultuur in Suriname behoeft niet af te stuiten op gebrek aan werkkrachten daar deze van Java in voldoende hoeveelheid onder contract te verkrijgen zijn. De arbeidskosten zijn echter hooger dan op Java, maar lager dan in de meeste katoenverbouwende streken der wereld. De katoencultuur eischt op een oogenblik veel handenarbeid en daarom is het logisch, dat zij in een gemengd bedrijf wordt opgenomen. De ontwikkeling van een mechanisch gedreven katoencultuur heeft de aandacht der landbouwtechnici in hooge mate getrokken. We mogen als vaststaand aannemen, dat de voor die cultuur noodige grondbewerking vrijwel geheel machinaal kan geschieden, terwijl volgens berichten ook het machinaal oogsten op loonende wijze mogelijk schijnt te zijn. In de „Scientific American" van Maart '22 komt een beschrijving voor van „,the succesful Cotton Picker”. Ik zal er het een en ander uit aanhalen. 
,The cotton industry, in which human labor has played „the important rôle for the 4000 or more years that cot„ton has been picked by hand, promises to become revo„lutionized by the advent of an electrically operated pick„er which has recently been perfected and placed in „practical operation on a plantation, at Little Rock, Ar„kansas, in the heart of the Northern cotton belt.

„This new electric device makes it possible for a person „to gather from 400 to 700 pounds of cotton a day, as „compared 70 to 150 by hand". De uitvinder is Stuckenborg uit Memphis, Tenn. U.S.

„L'Agronomie coloniale” 1922, blz. 399 wijst op de beteekenis dezer uitvinding voor streken langs de Niger en in Cambodja, waar door deze vinding de mogelijkheid van het totstandbrengen eener groote katoencultuur geopend wordt. Het artikel zegt o.m. : „Cette cueilleuse est remar"quable par la rapidité avec laquelle elle travaille" en wijst erop hoe jaarlijks voor millioenen aan katoen verloren gaan door te laat oogsten tengevolge van gebrek aan arbeidskrachten.

De machine van Stuckenborg wordt geëxploiteerd door de Intern. Gener. Electr. Cy.

Omtrent de bestrijding der gevreesde spanrupsen lezen wij in het Verslag van het Landbouwdepartement in Suriname over 1921: „In Juli tijdens den bloei trad in enkele „gedeelten van het veld de hier vroeger zoo gevreesde „spanrups op. Door tijdige bestuiving der katoenplanten „met parijsch groen en kalk 2 op 6 werden de rupsen vol„komen bestreden”.

In verband hiermede verwijs ik naar het interessante artikel van den Gouv. entomoloog in Suriname, den heer A. Reyne getiteld „Bestrijding van schadelijke katoeninsecten", voorkomende in het landbouwkundig tijdschrift West-Indië van Juli 1921.

Gezien de omstandigheden waaronder het insect in de Zuidelijke Staten van Noord-Amerika leeft, schijnt mij het bollweevil gevaar voor het kustgebied van Suriname niet groot. 
Britsch-Guyana (Demerary)

Volledigheidshalve meen ik nog het een en ander over de thans verlaten katoencultuur in Britsch Guyana te moeten mededeelen.

Eerst onder Hollandsch - maar vooral later onder Engelsch bewind - is in het tegenwoordige Britsch-Guyana katoen een belangrijk uitvoerproduct geweest. Volgens Rodway (Guiana. London 1912) bedroeg die uitvoer in 1799 3.593.053 lb, in $18017.622 .942 \mathrm{lb}$.

Op blz. 255 zegt hij:

„A century ago cotton was the principal export of De„merara and Berbice, its importance having been much „increased when the British took over these colonies in „1796. From the mouth of the Demerara to the Corentyne a "continuous line of this handsome shrub was under cultivat"ion $\left.{ }^{1}\right)$ which, in the new empolders, still impregnated „with salt, flourished to perfection: In 1807, however, „when the slave trade was stopped, further increase beca„me impossible, and then came a drop in price from the „competition of the Southern States.... Ultimately cot"ton fell off to nothing, and though it was attempted to „reintroduce its cultivation during the American war, „this was not a success. There are no particular reasons "why it should not be revived ${ }^{1}$ ) except the scarcity of la„bour, which might prevent a crop from being picked at „the proper time. A week or two makes little difference to ", the sugar-canes, but cotton would be blown away if not "picked to the day".

Volgens „The Encyc. Brit”. hebben de proeven door „the Board of Agric." in Britsch Guyana met Sea-Island katoen genomen geen bevredigende resultaten opgeleverd en het is aldaar tot heden niet gelukt een hybride te maken van zwaar dragende inlandsche katoen met Sea Island, die resistent is tegen ,anthracnose and boll-rot”. (Zie W. R. Dunstan-Papers and reports on cottoncultivat. ion 1911).

Dit neemt niet weg, dat de proeven tot heden met Sea-

1) Bij overname gecursiveerd. P. 
Island katoen in Suriname genomen hoopvol stemmen. Groote proefaanplantingen zijn gedurende eenige jaren noodig onder leiding van ter zake kundige menschen, terwijl evenals in het naburige Demerary getracht moet worden soorten te kweeken, welke naast een hooge productie groote marktwaarde bezitten en tevens zooveel mogelijk resistent zijn tegen ziekten.

\section{Conclusie}

Rekening houdende met alle kansen, mag m.i. worden geconcludeerd:

dat de mogelijkheid niet is uitgesloten, dat een loonende katoencultuur in Suriname is tot stand te brengen;

dat een soort kan worden verbouwd, welke een hooge marktwaarde bezit;

dat het land zich leent voor een grootendeels mechanisch gedreven cultuur, waardoor de opbrengsten per vlakteëenheid, die welke tot heden verkregen werden, belangrijk kunnen overtreffen.

\section{NASCHRIFT}

In het tijdschrift „United Empire”, ,The royal colonial institute journal" van Juli 1923 komt een interessant artikel voor over Tanganyika Territory van Capt. J. P. Tolland.

Tanganyika Territory bestaat uit een deel van het oude Duitsch Oost-Afrika, welk deel thans onder Engelsch bewind staat. Onder de uitvoer producten wordt katoen genoemd. Het land kan volgens schrijver een der belangrijkste katoenproduceerende landen der wereld worden. In 1913 werd dit product over een oppervlak van 32.000 acres door Europeesche planters, over 37.500 acres door inlandsche planters geplant.

Uit het rapport van een vertegenwoordiger van „The Empire Cotton Growing Committee” haalt schrijver het volgende aan:

"The Rufiji (Roefidsji) District is said to comprise some "of the finest cotton lands in the world. On the banks of 
„the river are flats and bottoms with soil of wonderful „depth and richness, covered only with elephant grass, „and therefore very easily cleared.... In my opinion these "vast riverine bottoms could only be adequaetely deve„loped by European capital. The country is suitable to „the use of steam ploughs and improved machinery, and, „if European capital is to be invested in cotton cultiva"tion in Tanganyika this is the area that I recommend for „the purpose.... No area offers larger returns from cot„ton cultivation than does this." De Rufiyi Rivier is over een afstand van 80 mijlen voor lichte stoomers bevaarbaar.

's-Gravenhage, Juni 1923 